\author{
Dr. sc. Nenad Đurđević, redovni profesor \\ Pravnog fakulteta Univerziteta u Kragujevcu
}

\title{
ZAŠTITA DECE U SPORTU
}

UDK: 34 : 796-053.2

Primljeno: 20. 01. 2019.

Prethodno znanstveno priopćenje

Prema Konvenciji o pravu deteta Ujedinjenih nacija iz 1989. godine, dete je ljudsko biće koje nije navršilo osamnaest godina života, ako se, na osnovu zakona koji se odnosi na dete, punoletstvo ne stiče ranije. Svakog dana širom sveta ogroman broj dece učestvuje u sportskim aktivnostima, rekreativnog ili takmičarskog tipa, na javnim prostorima, u školama, sportskim klubovima i drugim organizacijama. U tome im pomažu i podstiču ih brojni roditelji, treneri, sporski funkcioneri i druga lica. Sa bavljenjem sportom se počinje u sve mlađim uzrastima, što se temelji i na činjenici da je za decu fizička aktivnost prirodna forma kretanja koja podrazumeva izazov i uživanje zasnovano na igri. Za najveći broj dece sportske aktivnosti su pozitivno životno iskustvo, koje im omogućava unapređenje sopstvenih fizičkim mogućnosti, poboljšava zdravstveno stanje i razvija socijalne odnose sa drugima. Postoje, međutim, i ona deca za koje je bavljenje sportom skopčano i sa negativnim, često i traumatičnim, iskustvom, u vidu diskriminacije, nasilja, zlostavljanja, iskorišćavanja, prekomernog treniranja, oštećenja zdravlja, i negativnog uticaja na psihosocijalni i motorički razvoj ili obrazovanje. Sve javne vlasti i svi učesnici u sportu se takvim negativnim pojavama u sportu moraju odlučno suprotstavljati, kako pravnim tako i društvenim sredstvima. Sport u svim oblicima mora da bude pojedinačno dostupan svoj deci bez diskriminacije, uz omogućavanje jednake mogućnosti dečacima i devojčicama i uz uvažavanje posebnih potreba svakog starosnog uzrasta, Autor u radu ukazuje na dobrobiti koje bavljenje sportom donosi deci, analizirajući, pri tom, tipične oblike zloupotreba dece u sportu i potrebne mere za zaštitu dece od različitih oblika diskriminacije, nasilja, zlostavljanja i iskorišćavanja u sportu. U radu se ukazuje na mere koje se u tom pravcu preduzimaju na međunarodnom nivou, kao i na rešenja uneta u Zakon o sportu Republike Srbije iz 2016. godine u cilju posebne zaštite dece u sportu.

Ključne reči: zaštita dece u sportu, diskriminacija, nasilje, zlostavljanje, zloupotreba, iskorišćavanje, sport, deca

Za najveći broj dece sportske aktivnosti su pozitivno životno iskustvo, koje im omogućava unapređenje sopstvenih fizičkim mogućnosti, poboljšava zdravstveno stanje i razvija socijalne odnose sa drugima. Postoje, međutim, i ona deca za koje je bavljenje sportom skopčano i sa negativnim, često i traumatičnim, iskustvom, u vidu diskriminacije, nasilja, zlostavljanja, iskorišćavanja, prekomernog treniranja, oštećenja zdravlja, i negativnog uticaja na psihosocijalni i motorički razvoj ili obrazovanje. U takmičarskom sportu deca su izložena preterano napornim treninzima, zloupotrebi tela, neumerenoj komercijalizaciji, ilegalnom radu, dopingu, diskriminaciji, korupciji i nasilju. Ovakve ozbiljne pretnje kojima su deca izložena, prete moralnim vrednostima, slici i ugledu sporta i deformišu njegovu prirodu, kao 
i ulogu u promociji zdravlja i obrazovanja. Zbog toga, jedan od glavnih prioriteta vođenja sportske politike treba da bude zaštita dece i obezbeđenje njihovog harmoničnog razvoja, kako bi se izbegli fizički i psihički poremećaji koji mogu da ih upropaste za ceo život. ${ }^{1}$ Pri tom je, po našem mišljenju, od suštinskog značaja da deca sportisti pre svega tretiraju kao deca a tek onda kao sportisti.

Kao prethodno pitanje se, međutim, postavlja definisanje pojma ,zaštite“ i pojma dece. Često se smatra da pojmovi zaštita dece i sigurnost (bezbednost) dece imaju isto značenje, mada među njima postoje značajne razlike. Sigurnost dece (safeguardng children) podrazumeva da se sva deca zaštite od svih šteta, zlostavljanja, nasilja, eksploatacije i zanemarivanja, što podrazumeva proaktivno delovanje svih učesnika u sistemu sporta, kako bi se obezbedilo da deca budu bezbedna prilikom učešća u sportskim aktivnostima. Sigurnost dece ima preventivnu komponentnu i usmerena je na obezbeđenje delotvornih politika, praksi i procedura u cilju ograničenja šteta koje se javljaju, kao i primene mera za izveštavanje, istraživanje i rešavanje sumnji i incidenata. Suštinski, sigurnost dece u sportu znači niz akcija koje pomažu da sva deca koja učestvuju u sportu imaju pozitivno iskustvo. Za razliku od toga, zaštita dece (child protection) štiti pojedinačno dete za koje je utvrđeno da je u opasnosti od štete, zlostavljanja, nasilja, eksploatacije ili zanemarivanja. Zaštita dece čini deo sigurnosnih mera za decu, ali treba je posmatrati kao poslednju liniju odbrane u obezbeđenju sigurnosti dece. ${ }^{2}$

Drugi problem nastaje čim se upustimo u definisanje pojma ,dete“. Problem se dodatno usložnjava sa stanovišta ,deteta sportiste“, imajući u vidu razlike između pravnog i sportskog „doba“ nekog lica. Olimpijska prvakinja u gimnastici koja ima 12 godina je, nesumnjivo, i maloletnik i dete ali je istovremeno i vrhunski sportista. U nekim sportovima, deca od 12 do 13 godina mogu dostići najviše nivoi takmičarskih performansi, dok se u drugim, puna sportska zrelost može doći tek u odraslom dobu. Šta se smatra "mladim - juniorom " u jednom sportu, u drugom može značiti ,senior“ (odrasli), što dovodi do toga da definicije pravnog i sportskog doba ne znače obavezno isto, usled čega je, na kraju, u sportu razlika između odraslih i dece često zbunjujuća. Deca sportisti, posebno ako su veoma talentovana i bave se sportom na visokom nivou, mogu se tretirati kao odrasli i pripisivati im se odgovornosti odraslih, ili se od njih može očekivati ponašanje koje je iznad njihove stvarne životne dobi. U takvim okolnostima, lako je pretpostaviti da dete ne treba zaštitu odraslih, usled čega se nasilje nad decom može zanemariti, neprepoznati ili biti opravdavano. ${ }^{3}$

Ako posmatramo pravo Evropske unije lako je uočiti da ne postoji jedinstvena, zvanična definicija ,deteta“ utvrđena u nekom izvoru prava EU ili sudskoj praksi. Šta više, definicija deteta se u pojedinim pravnim izvorima može znatno razlikovati

1 Videti zaključke Prve konferencije EU o sportu, održane u Olympia (Grčka) iz 1999, prevod u: Nenad Đurđević, Javne vlasti i sport, Kragujevac, 2007, str. 732-738.

2 Videti, https://www.sportanddev.org/sites/default/files/downloads/international-safeguards-forchildren-in-sport-version-to-view-online.pdf

3 UNICEF Innocenti Research Centre - Protercting children from violence in sport - a review with a focus on industrialized countries, Florence, Italy, 2010, str. 4. 
u zavisnosti od regulatornog konteksta. Situacija nije bolja ni ako se pogledaju akta Saveta Evrope, pa se tako za označavanje iste kategorije lica čas koristi pojam "deca", čas "deca i mladi" ili samo "mladi". Mi ćemo zato za potrebe ovog rada prihvatiti definiciju datu u Konvenciji Ujedinjenih nacija o pravima deteta iz 1989. godine, prema kojoj je dete bilo koje ljudsko biće koje nije navršilo osamnaest godina života, ako se, na osnovu zakona koji se odnosi na dete, punoletstvo ne stiče ranije (čl. 1).

Problemu zaštite dece u sportu može se pristupiti na različite načine. Nama se čini da se ono najbolje može razmotrimo na sličan način kako se postavljaju tzv. zlatna pitanja kriminalistike: ko se štiti, šta se štiti, od čega se štiti, od koga se štiti i na koji način se štiti?. Svako od ovih pitanja bi zasluživalo poseban poseban obiman rad, pa ćemo se zadržati samo na suštini pitanja o tome šta bi se trebalo štititi i od čega, smatrajući, pri tom, da odgovor na ta pitanja ukazuje na izvor pretnji po decu u sportu i na mere koje bi trebalo preduzeti.

\section{1. ŠTA TREBA ŠTITITI?}

Prema čl. 1. Međunarodne povelje o fizičkom obrazovanju i sportu, usvojenoj od Generalne skupštine UNESKOa 1978. godine, „bavljenje sportom i fizičko obrazovanje su osnovna ljudska prava svih". ${ }^{4}$ Druga strana medalje bavljenja dece sportom jesu, međutim, brojne opasnosti koje dovode $u$ pitanje ciljeve utvrđene navedenim čl. 1. Međunarodne povelje o fizičkom obrazovanju i sportu. Zbog toga je i Generalna skupština UN u Rezoluciji 60/9 „Sport kao sredstvo za promociju obrazovanja, zdravlja, razvoja i mira“ iz 2006. godine, ${ }^{5}$ podvukla značaj Konvencije o pravima deteta za zaštitu mladih sportista. Iako je Konvencija o pravima deteta jedna od najviše ratifikovanih konvencija UN, sa 192 ratifikacije, ona je u isto vreme i jedna od najmanje primenjenih. To je naročito vidljivo u oblasti dece u sportu gde ona u opšte ne uživaju sličnu zaštitu koja je pružena deci u industriji zabave, kao što nema zemlje u svetu koja je donela specifično i obuhvatno radno zakonodavstvo $\mathrm{u}$ vezi mladih sportista.

Eliminacija štetne strane sporta mora biti učinjena tako da on ostane pozitivno i ispunjavajuće iskustvo za svu decu. Konvencija o prvima deteta može u tom pogledu da pomogne jer: 1) Sport se bori protiv diskriminacije tako što omogućava integraciju grupa koja se ugrožene njome, kao što su devojčice, deca pripadnici manjinskih grupa, deca koja žive u siromaštvu, deca sa hendikepom, itd. (čl. 2); 2) Sport obezbeđuje mogućnost svim grupama dece, koja imaju potrebe za posebnom

4 „1.1. Svako ljudsko biće ima osnovno pravo na fizičko obrazovanje i sport, koji su od suštinskog značaja za razvoj ličnosti. Sloboda da se razvijaju fizički, intelektualni i moralni kapaciteti kroz fizičko obrazovanje i sport mora biti zagarantovana, kako kroz obrazovni sistem tako i kroz druge aspekte društvenog života; ... 1.3. Posebne mogućnosti se moraju pružiti mladima, uključujući i decu predškolskog uzrasta, starima, $i$ hendikepiranima da razviju, u potpunosti, svoje ličnosti kroz fizičko obrazovanje $i$ sportske programe prilagođene njihovim zahtevima.", Videti čl. 1. Međunarodne povelje o fizičkom obrazovanju i sportu. Prevod Povelje može se videti u: Đurđević, op.cit., str. 386-391.

5 https://www.sportanddev.org/sites/default/files/downloads/a_res_58_5_english.pdf 
zaštitom, 3) da imaju jednak pristup sportu - kao što su: deca sa hendikepom, deca koja žive u socijalnim i sličnim institucijama, deca koja žive u popravnim domovima, deca izbeglice, deca koja se nalaze na rehabilitaciji, deca koja rade (čl. 20, 22, 23. i 31); 4) Sport daje moć mladima tako što im omogućava da učestvuju u društvenom životu, da steknu sliku o sebi, razviju samopouzdanje i unaprede se, pri tom poštujući odrastanje i sve veće potencijale deteta, uz uvažavanje prava i odgovornosti odraslih (čl. 5. i 12-17); 5) Sport promoviše nenasilje, ohrabruje fer plej, i usmerava energiju dalje od potencijalnih nasilja (čl. 19. i 29) 6) Sport je zdrav i promovišući i obezbeđujući, zdrave i sigurne, uslove za bavljenje sportom jačamo javno zdravlje (čl. 24); 7) Sport može podržati razvoj talenata i omogućiti deci da razviju svoje potencijale do krajnjih granica (čl. 29.1a); 8) Sport je pozitivna rekreaciona aktivnost: bavljenje sportom udaljava decu i adolescente od devijantnih ponašanja (čl. 31); 9) - Sport je sredstvo za rehabilitaciju i reintegraciju: deca, žrtve nasilja, mogu koristiti sport kao sredstvo koje će pomoći njihovom fizičkom i psihičkom oporavku i socijalnoj reintegraciji (čl. 39).

Dečja prava garantovana Konvencijom o pravima deteta su, po našem mišljenju; upravo ono što treba štiti tokom njihovog bavljenja sportom, s tim da su neka od njih i posebno ugrožena. ${ }^{6} \mathrm{U}$ tom pogledu bismo posebno izdvojili:

1) Pravo na zaštitu od diskriminacije (čl. 2);

2) Pravo da interesi deteta budu osnovna briga oba roditelja, na osnovu principa najboljeg interesa deteta (čl. 3. i 18);

3) Pravo na zaštiti od fizičkog ili mentalnog nasilja, povreda, zloupotreba (pa i seksualnih), zanemarivanja, nemarnog odnosa, maltretiranja, eksploatacije (čl. 19 i čl. 36);

4) Pravo na najviši nivo zdravstvene i medicinske zaštite;

5) Pravo mentalno zaostalog ili sa fizičkim invaliditetom deteta da uživa pun i dostojan život;

6) Pravo na igru i rekreaciju koja odgovara uzrastu deteta (čl. 31);

7) Pravo na zaštitu od eksploatacije i rada na poslu koji može biti opasan ili ometati obrazovanje deteta ili štetiti zdravlju deteta, odnosno njegovom fizičkom, mentalnom, duhovnom, moralnom ili socijalnom razvoju;

8) Pravo na zaštitu od svih oblika seksualnog izrabljivanja i seksualne zloupotrebe (čl. 34);

9) Pravo na zaštitu od trgovine decom (čl. 35);

6 Zaštita prava deteta" inače je jedan od ciljeva EU na koje Ugovor o Evropskoj uniji (2012) (član 3 (3)) stavlja posebni naglasak. "Prava deteta" su takođe sadržana u Povelji o osnovnim pravima Evropske unije (2000), gde je, između ostalog, priznato da "deca imaju pravo na takvu zaštitu i brigu koja je potrebna za njihovu blagostanje " $\mathrm{i}$ da "u svim postupcima koji se odnose na decu, bilo da ih preduzimaju javni organi ili privatne institucije, najbolji interes deteta mora biti primarno pitanje" (član 24. al. 1-2). Ne čudi onda i što Evropska unija i Savet Evrope konstantno u brojnim svojim dokumentima ističe potrebu za adekvatnom zaštitom dece, poput: Agende EU o prvima deteta, Smernice EU za promociju i zaštitu prava deteta, Strategija EU 2020 - COM (2008) 55 final (cilj da se ograniči učešće ranog napuštanja škola na manje od 10\%); Rezolucija Evropskog Saveta o drugom Evropskom radnom planu za sport (2014-2017); Rezolucija Saveta Evrope o sprečavanju seksualnog uznemiravanja i zlostavljanja žena, mladih i dece u sportu $(3 / 2000)$. 
10) Pravo na zaštitu od svih oblika okrutnih, neljudskih ili ponižavajući postupaka;

11) Pravo na slobodu udruživanja (čl. 15);

\section{OD ČEGA TREBA ŠTITITI DECU U SPORTU?}

Prema članu 7. Međunarodne povelje o fizičkom vaspitanju i sportu, zaštita etičkih i moralnih vrednosti fizičkog obrazovanja i sporta mora biti predmet neprestane brige svih. Vrhunski i rekreativni sport moraju biti zaštićeni od svakog oblika zloupotrebe. Ozbiljne pretnje sa kojima se oni susreću, kao što su doping, nasilje i komercijalna zloupotreba, prete moralnim vrednostima, slici i ugledu i deformišu njihovu prirodu i menjaju njihovu ulogu u promociji zdravlja i obrazovanja. Posebno je važno da sve sportske vlasti, sportisti i sportistkinje budu svesni rizika za sportiste, posebno decu, od preteranog i neprikladnog treninga i psiholoških pritisaka svake vrste.

\subsection{Zaštita od rizika svojstvenih sportu}

Svako bavljenje sportom skopčano je sa većim ili manjim rizikom. Ukinuti taj rizik, znači ukinuti i sport. Kod svih vrsta sportova događaju se nesreće (udesi) u kojima dolazi do oštećenja učesnika i drugih lica. Rizici udesa su tim veći što su veći zahtevi u pogledu brzine, snage, vičnosti, smelosti i izdržljivosti. Tokom vremena, broj sportskih nesreća stalno se povećava. Uzroci tome su raznoliki. S jedne strane, jako su povećani rezultati, pa time i rizici, a s druge strane, nove mere za sprečavanje udesa ne prate takav razvoj sporta. ${ }^{7}$ Tome treba dodati i sve veću masovnost sporta. Stepen rizika varira u zavisnosti od vrste sporta i načina na koji se on odvija. Tu, pre svega, treba praviti razliku između takmičraskog i masovnog (rekreativnog) sporta. Karakteristika takmičarskog sporta, nevezano za nivo rezultata i dostignuća, jeste snažan nagon učesnika da se maksimalno fizički angažuju do svojih granica i poboljšaju svoje sposobnosti. ${ }^{8}$ Posebno su deca ugrožena izlaganjem rizicima svojstvenim određenim sportskim aktivnostima, naročito u situaciji kada se tek upuštaju u bavljenje sportom, dok su u fazi obuke, dok nisu pod nadzorom trenera ili instruktora ili kada precenjujući svoje sportsko „umeće“ preduzmu radnje koje nadilaze njihove fizičke ili umne sposobnosti. Najveći broj povreda se događa tokom trenažnog procesa (62\%) i one mogu biti izazvane brojnim faktorima, pre svega fizičkim - umor, bolest, pretreniranost, gruba igra, neadekvatna trenažna i takmičarska opterećenja itd, ali i psihološkim, koji su primarno povezani sa stresom (povećana uznemirenost, poremećaj pažnje, povećanje mišićne napetosti). Deca su pod velikim rizikom od povređivanja i zbog razvojem uslovljenih manjih

7 Reichard Eichenberger, Zivilrechtliche Haftung des Veranstalters sportlicher Wettkaempfe, Diss., Zuerich, 1973, str. 2.

8 Evropske preporuke za učestvovanje u rekreativnom i takmičarskom sportu, urednik Nenad Dikić, Sporska medicina, br. 2/2007, str. 6. 
sposobnosti da procene rizik, zbog lošije koordinacije, sporijeg vremena reagovanja, manje preciznosti, naglog povećanja težine, intenzivnog rasta zglobova i udova itd.. ${ }^{9}$

Zakon o sportu Republike Srbije $(Z S)^{10}$ o svemu ovome vodi računa utvrđujući da bavljenje sportom mora biti „bezbedno“ (čl. 4. st. 2) i da je zabranjeno decu izlagati sportskim aktivnostima i fizičkim vežbanjima koja mogu da ugroze ili pogoršaju njihovo zdravstveno stanje ili da negativno utiču na njihov socijalni i motorički razvoj (čl. 22. st. 2). Jedna od mera da se to obezbedi je i zabrana da sa decom u sportu rade lica koja nemaju odgovarajuće više ili visoko obrazovanje u oblasti fizičkog vaspitanja i sporta ili ako pored osnovne stručne osposobljenosti nisu i posebno (dodatno) stručno osposobljena za rad sa decom (čl. 27. st. 4. ZS).

\subsection{Zaštita od ugrožavanja zdravlja}

U savremenom svetu je opšte prihvaćeno da su sportske aktivnosti korisne kako za razvoj ličnosti tako i za održavanje dobrog zdravlja, poboljšanje fizičkih kvaliteta, većeg ličnog zadovoljenja, boljeg i svrsishodnijeg korišćenja slobodnog vremena i poboljšanje kvaliteta života. To se najbolje sublimuje u izreci: sport je prevencija - sport je medicina - sport je zdravlje. Odnos sporta i zdravlja može se, međutim, posmatrati iz dva ugla. S jedne strane se nalazi pitanje unapređenja zdravlja kroz sport, a na drugoj strani je problem zaštite zdravlja lica koja se bave sportskim aktivnostima, posebno dece. Prvo pitanje je mnogo šire od drugog i deo je šireg problema odnosa društva i sporta. Drugo pitanje se bavi različitim aspektima uticaja bavljenja sportom i fizičkim aktivnostima na zdravlje lica koja ih upražnjavaju, i kada se govori o zdravstvenoj zaštiti sportista obično se misli na njega. Ova dva pitanja proističu iz činjenice da u samoj osnovi odnosa sporta i zdravlja postoji jedna protivurečnost. Proračuni pokazuju da već relativno male promene u učestalosti fizičkih aktivnosti, odnosno kretanja (npr. smanjenje neaktivnog stanovništva za 10 do 15\%) mogu da smanje broj smrtnih slučajeva stanovništva za 1,5 do 2\%. Međutim, sa sportskom fizičkom aktivnošću povezan je i obrnuti fenomen. Nesrećni slučajevi, povrede i različite štete spadaju u sastavni deo bavljenja sportom. ${ }^{11}$ Zbog toga, svaki dečak ili devojčica koji se bavi takmičarskim sportom mora imati mogućnost medicinskog pregleda kada god njihovi roditelji, doktori ili treneri smatraju da je to potrebno, pri čemu kad se dete bavi takmičarskim sportom, potrebno je da ima poseban medicinski karton koji se vodi sve dok se takmičarski sport praktikuje. ${ }^{12}$ str. 44.

9 Lj. Bačanac - N. Petrović - N, Manojlović, Priručnik za roditelje mladih sportista, Beograd, 2009,

10 „Sl. glasnik RS“, br. 10/2016.

11 Felix Gutzwiller, Sport und Bewegung - Grundlage fuer die gesundheit, ww.svl.ch/svlimmat sporthealth.html

12 Smatrajući da su sportske aktivnosti blagotvorne ne samo za razvoj ličnosti već i za postizanje dobrog zdravlja kod svih, Komitet ministara Saveta Evrope se zdravstvenim aspektima sporta najdetaljnije bavio u Rezoluciji br. (70)7: "O medicinskim aspektima sporta”, usvojenoj 7. marta 1970. godine. Videti, Đurđević, op.cit., str. 679-682. 
Zakon o sportu Republike Srbije je zaštiti zdravlja dece koja se bave sportom posvetio posebnu pažnju. Pored ranije navedene zabrane iz čl. 22. st. 3. ZS, zabranjeno je i da se dete uključi u organizovane sportske aktivnosti u organizaciji u oblasti sporta ako mu nije utvrđena opšta zdravstvena sposobnost za obavljanje sportskih aktivnosti (čl. 19. st. 5. ZS). Ako je dete, međutim, uključeno u sportska takmičenja, onda u tim takmičenjima može učestvovati samo ako mu je u periodu od šest meseci pre održavanja sportskog takmičenja utvrđena opšta zdravstvena sposobnost za obavljanje sporskih aktivnosti (čl. 19. st. 1. ZS), s tim da deca takmičari mlađa od 16 godina i deca takmičari mlađih kategorija koja se takmiče u starijim kategorijama moraju pored opšte zdravstvene sposobnosti imati utvrđenu i posebnu zdravstvenu sposobnost za bavljenje određenim sportskim aktivnostima (čl. 19. st. 2. ZS i čl. 3. st. 3. Pravilnika o utvrđivanju zdravstvene sposobnosti sportista za obavljanje sportskih aktivnosti i učestvovanje na sportskim takmičenjima ${ }^{13}$ ). Troškovi utvrđivanja ovih zdravstvenih sposobnosti za maloletne sportiste uzrasta od 6 do 14 godina obuhvaćeni su obaveznim zdravstvenim osiguranjem u skladu sa zakonom, kada se zdravstvena sposobnost utvrđuje u zdravstvenoj ustanovi iz plana mreže zdravstvenih ustanova ili zavodu nadležnom za sport i medicinu sporta (čl. 19. st. 6. ZS). Slično je stanje i kada je u pitanju školski sport. Učenici i studenti mogu biti uključeni u vannastavne sportske aktivnosti i sporska takmičenja ako im je prethodno utvrđena zdravstvena sposobnost za bavljenje školskim sportom (čl. 143. st. 9. ZS). Troškovi utvrđivanja zdravstvene sposobnosti učenika za bavljenje školskim sportom obuhvaćeni su obaveznim zdravstvenim osiguranjem, u skladu sa zakonom, kada se utvrđivanje zdravstvene sposobnosti vrši u zdravstvenoj ustanovi (čl. 12. ZS). Utvrđivanje zdravstvene sposobnosti učenika uzrasta od 6 do 14 godina života vrši izabrani lekar pedijatar nadležne zdravstvene ustanove tokom obaveznog sistematskog pregleda, odnosno lekar specijalista sportske medicine ili pedijatrije nadležne zdravstvene ustanove kada se utvrđivanje zdravstvene sposobnosti vrši izvan sistematskog pregleda (čl. 143. st. 10. ZS).

Jedan od problema zaštite zdravlja dece u sportu je i pitanje dopinga. ${ }^{14}$ Doping i sport su dva suštinski suprotna koncepta, i posebno je štetan kada su u pitanju deca. Svetski andidoping kodeks sve slučajeve dopinga maloletnih sportista tretira kao tešku povredu antidoping pravila. Isto je i kad je u pitanju Zakon o sprečavanju dopinga u sportu Republike Srbije ${ }^{15}$. Šta više, prema čl. 38. st. 2. Zakona o sprečavanju dopinga u sportu, ko maloletnom sportisti u cilju dopinga u sportu da ili propiše ili izda ili na sportisti primeni doping sredstvo, ili navede, pomogne, ili na drugi način omogući sportisti da upotrebi doping sredstvo, kazniće se kaznom zatvora od dve do deset godina (teži oblik krivičnog dela: omogućavanje upotrebe doping sredstava).

13 „Sl. glasnik RS“, br. 15/2012

14 Videti, Nenad Đurđević, "Zaštita zdravlja sportista i sprečavanje dopinga u sportu u Republici Srbiji”, Zbornik radova Pravnog fakulteta u Splitu, br. 4/2011, str. 729-748.

15 „Sl. glasnik RS“, br. 111/2014. 


\subsection{Zaštita od onemogućvanja bavljenja sportom usled siromaštva}

Savremni sport služi ne samo fizičkoj razonodi čoveka već je postao veoma značajno privredno dobro koje značajno učestvuje u ukupnom privrednom životu savremenih društava. Sport je postao samostalni privredni sektor, što je neminovno dovelo i do ogromnog povećanja izdvajanja građana za sport. Jedan deo tih izdataka vezan je i za izdatke koje imaju roditelji da bi omogućili svojoj deci da se bave sportom. Iskustvo pokazuje da $67 \%$ dece uđe u sport u uzrastu od šest do 10 godina, bilo preko raznih ,škola sporta“ (škola tenisa, škola fudbala, škola košarke i s.), sportskih kampova ili preko sportskih klubova. Roditelji, pri tom, plaćaju ne samo „ulaznicu“ u vidu, najčešće, mesečne članarine, već obezbeđuju svojoj deci i sportsku opremu, sportske rekvizite i sve drugo što je potrebno da bi se njihovo dete moglo baviti sportom. Klub, sportski kamp, sportska škola i slične organizacije obezbeđuju, po pravilu, jedino stručnu sportsku obuku i sportski objekat na kome se obuka vrši, naplaćujući za to određenu naknadu. Suštinski se, pri tom, radi o pružanju stručnih usluga, ali se to najčešće „, krije“ formom učlanjavanja u neprofitno sportsko udruženje (ne plaćaš oporezivu uslugu već članarinu sportskom udruženju). Takva situacija dovodi, na kraju, do toga da se sportom, ili barem određenim sportom, bave deca čiji roditelji mogu to da plate. U društvima sa niskim životnim standardom stanovništva troškovi uključivanja dece u sport mogu biti toliki da faktički onemogućavaju njihovo bavljenje sportom, nezavisno od sportskog talenta, pogotovu ako roditelj ima više dece koja žele da se bave sportom.

Kako bi se olakšalo učešce decu u sportu, Zakon o sportu Republike Srbije je propisao visinu mesečne članarine za decu u sportskim udruženjima, i ona ne može biti veće od jedne desetine prosečne zarade na nivou Republike Srbije utvrđene od strane republičkog organa nadležnog za poslove statistike za prethodnu budžetsku godinu (čl. 40. st. 7).

\subsection{Zaštita od odluka suprotnih najboljem interesu deteta}

Danas više nije sporno da su deca ugrožena populacija kojoj je potrebna posebna pažnja i zaštita. Najprirodniji pružaoci te zaštite su roditelji. Kada se dete uključi u sport, roditelji neminovno postaju deo njegovog sportskog života, ali ujedno će i ceo porodični život najmanje sledećih 10 godina biti obeležen zahtevima bavljenja deteta sportskim aktovnostima ako ono pokaže potencijal za postizanje vrhunskih sportskih rezoltata. Prirodno je da roditelji žele svom detetu najbolje od bavljenja sportom, ali oni mogu, međutim, i zloupotrebiti i iskoristiti svoju moć nad detetom. Brojni su primeri gde roditelji hoće da svoje neostvarene ambicije u sportu ili u životu ostvare preko dece i pri tome ne biraju sredstva, izlažući decu preteranom pritisku i ne vodeći računa o najboljem interesu deteta. Problem je posebno izražen u situaciji kada samo jedan roditelj nameće svoju volju detetu ili odlučuje u njegovo ime, ne vodeći računa niti o željama detete niti o mišljenju 
drugog roditelja. Opasnost po najbolje interese deteta kulminira u situaciji kada se odnosi u porodici ne odvijaju skladno i funkcionalno. Čak i kada je u tom pogledu sve u redu, nije lako biti dobar sportski roditelj - nije lako naći pravu meru između suvišnog pritiska, preterane identifikacije i nerealnih očekivanja, s jedne strane, $\mathrm{i}$ potupne ravnodušnosti, nezainteresovanosti i /ili nedovoljne uključenosti u sport svoje dece, s druge strane. ${ }^{16}$

Tokom sportske karijere deteta nebrojano puta će se postaviti dilema - „šta je u njegovom najboljem interesu?"،, i ko o tome treba da odluči. Dve ključne sile koje danas oblikuju pravni položaj deteta i predstavljaju izvorište pravne regulative o deci jesu princip najboljeg interesa deteta i prava deteta na participaciju. Najbolji interes deteta je cilj, a prava deteta na participaciju su način za ostvarivanje tog cilja. Ne može se ostvarivati najbolji interes deteta bez poštovanja njegovih prava na participaciju, kao što ta prava deteta mogu funkcionisati jedino kroz najbolji interes deteta. ${ }^{17}$

Zakon o sportu Republike Srbije iz 2016. godine je doneo suštinske novine kada je u pitanju vođenje računa o najboljem interesu deteta i ostvarivanju njegovih parcipativnih prava. Dete može biti član sportksog udruženja nezavisno od godina starosti, s tim da izjavu o pristupanju, odnosno učlanjenju u sportsko udruženje za dete koje nije navršilo 14 godina daje dete uz prethodnu pisanu saglasnost roditelja, odnosno staratelja (čl.. 49. st. 2. i 4. ZS). Dete sa navršenih 14 godina može samostalno dati izjavu o učlanjenju. Ukoliko dete zaključuje ugovor sa sportskom organizacijom (ugovor o stipendiranju za sportsko usavršavanje, ugovor o bavljenju sportom ili ugovor o radu), on se može punovažno zaključiti samo uz pisanu saglasnost oba roditelja, odnosno staratelja, overenu u skladu sa zakonom, a u protivnom je ugovor ništav (čl. 10. 6. i 10. ZS). Ugovor sa sportskom organizacijom uvek potpisuje sportista, čak i kada je maloletan (čl. 12. st. 2. ZS). Pisana i overena u skladu sa zakonom saglasnost oba roditelja, odnosno staratelja potrebna je i za zaključenje ugovora o posredovanju između deteta i organizacije za sportsko posredovanje (sportskih menadžera), kao i za zaključenje ugovora o ulaganju u dete sportistu, na osnovu koga neko lice ima pravo na deo prihoda koji proizilazi iz obavljanja njegove sportske aktivnosti (čl. 94. st. 9. i 14. ZS). ${ }^{18}$

\footnotetext{
16 Lj. Bačanac - N. Petrović - N, Manojlović, Priručnik za roditelje mladih sportista, Beograd, 2009 , str. 6 .

17 Veljko Vlašković, P"ravo deteta na mišljenje i najbolji interes deteta sa težištem na pristupu Komiteta za prava deteta“, Zbornik radova Pravnog fakulteta u Nišu, br. 75/2017, str. 196.

18 Kod davanja saglasnosti na zaključenje ugovora između maloletnog sportiste i sportske organizacije ne radi se o odlukama o pitanjima od svakodnevnog značaja za život deteta već o odlukama od bitnog uticaja na život deteta, čije se posledice po razvoj deteta ne mogu uopšte otkloniti, odnosno otkloniti bez velikih poteškoća. Zbog toga je za davanje saglasnost potrebno zajedničko i sporazumno odlučivanje roditelja. Stupajući u ugovorni odnos sa određenom sportskom organizacijom maloletni sportista bitno ograničava svoju slobodu. Sve dok ugovor ne istekne on ne može promeniti klub (čl. 50. st. 3. Zakona o sportu).
} 


\subsection{Zaštita od eksploatacije i ugrožavaja razvoja putem transfera (prelaska) iz kluba u klub}

Danas više nije potrebno dokazivati i posebno obrazlagati kako su sportisti jedan od ključnih "resursa" za stvaranje profita različitih učesnika u sistemu sporta. Da bi se obezbedio stalni priliv kvalitetnih sportista, sportski klubovi teže da "regrutuju" talentovane za određeni sport dečake i devojčice što je moguće ranije. Međutim, pored klupskih sportskih škola sve više se razvijaju i razne "privatne" sportske škole (škola fudbala, škola odbojke, škola košarke), u želji da se stvori buduća sportska zvezda od koje će kasnije "profitirati”. U tom pogledu fudbal i košarka prednjače, ali ni drugi sportovi ne zaostaju preterano, posebno u profesionalnom sportu.

Savremeni vrhunski sport doveo je do toga i da navijači, s jedne strane, žele da njihovi timovi igraju na najvišem nivou, ali s druge strane, oni brinu i o poreklu i nacionalnosti igrača koji igraju za njihov omiljeni tim. Ta dilema se u okviru međunarodnih sportskih federacija razrešava donošenjem sportskih pravila o transferu igrača. Međutim, tokom vremena su ta pravila značajno doprinela različitim nepravilnostima kada su u pitanju maloletni igrači, naročito iz ekonomski slabo razvijenih zemalja. Naročito su evropski fudbalski klubovi iskoristili razne rupe u propisima o transferu da bi regrutovali mlade igrače iz inostranstva i zadržali mlade igrače. Neke od ovih mera uključuju otvaranje radnih mesta za roditelje dece kako bi mogli legalno da se presele u Evropu, sklapanje ugovora sa maloletnicima u ranoj dobi, i korištenje rupa u zakonima o imigracijama širom Evropske unije ("EU”). Najgori slučajevi su vezani za trgovinu maloletnicima iz Afrike od strane nelicenciranih sportskih agenata pri njihovom transferu u evropske klubove, uz značajno učešće i raznih fudbalskih akademija. ${ }^{19}$ Umesto uspešne sportske karijere, najčešće završe napušteni, u stranoj zemlji, bez novca i poznavanja jezika, bez radne dozvole i dozvole boravka, radeći sporadično u okviru sive ekonomije, pri čemu većina njih nije čak u stanju da se vrate kući, delom zbog toga što nemaju novca za povratak kući, a delom i stoga što bi po povratku bili percipirani kao neuspešni od strane porodice koja se za njih žrtvovala. ${ }^{20}$

Nisu, međutim, samo pravila o transferima maloletnih sportista od velikog zanačaja za njihovu zaštitu. ${ }^{21} \mathrm{Na}$ primer, kada je UEFA povećala kvotu tzv. home-grown igrača na 8, evropski klubovi su dobili veći poticaj da traže mlade međunarodne talente da bi ih upisali u svoje lokalne akademije za obuku, jer se ti igrači mogu računati u kvoti koju je dobio domaći klub. Klubovi takođe traže mlade talente jer su mlađi igrači uglavnom jeftiniji, što klubovima omogućava da ostvare značajan profit. Mlađi igrači dolaze po nižoj kupovnoj ceni, što omogućava klubovima da ostvare značajan profit

19 Christina Lembo, FIFA Transfer Regulations and UEFA Player Eligibility Rules: Major Changes in European Football and the Negative Effect on Minor, Emory International Law Review, http://aw.emory. edu/eilr/content/volume-25/issue-1/comments/fifa-transfer-regulations-uefa-eligibility-rules-europeanfootball-minors.html

20 Ines Medić, „Pravna zaštita maloljetnih sportaša u kontekstu prava EU”, Zbornik radova Pravnog fakulteta u Splitu, br. 4/2015, str. 1107-1108.

21 O zaštiti prava maloletnih sportista na nivou Evropske unije i od strane FIFA i UEFA više videti, Medić, op. cit., str. 1114-1131. i Rob Simon, Protection of minors vs. European law, Bulletin 1/2010, str. 165-183, http://www.dvdw.nl/media/28537/simons_protection_of_minors_vs_european_law.pdf 
ako igrači imaju uspešnu profesionalnu karijeru. Evropski klubovi imaju podsticaj da kupuju igrače u ranoj dobi kako bi mogli da ispune svoje domaće kvote i ostvare profit kada igrač stekne pravo da potpiše profesionalni ugovor, čak i ako to znači rizikovanje dobrobiti dece. ${ }^{22}$ Čak i ako samo jedan ili dva od ovih mladih igrača uspeju profesionalno, klubovi će znatno zaraditi, što ih ohrabruje da pronađu što je moguće više praznina u propisima FIFA-e o transferu maloletnika $\mathrm{i}$ da iskoriste te rupe za

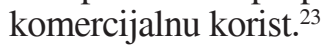

Zakon o sportu Republike Srbije iz 2016. godine je po prvi put, u čl. 18. st. 4-8, regulisao pitanje transfera maloletnih sportista, i to kako međunarodnih tako i nacionalnih. Međunarodni transfer, odnosno prelazak maloletnog sportiste u stranu sportsku organizaciju nije dozvoljen, osim u posebnim slučajevima utvrđenim sportskim pravilima nadležnog međunarodnog sportskog saveza. Nacionalni transfer, odnosno prelazak maloletnog sportiste u domaću sportsku organizaciju izvan mesta prebivališta maloletnog sportiste takođe nije dozvoljen, osim ako je prelazak odobren od strane nadležnog nacionalnog granskog sportskog saveza u skladu sa kriterijumima i u postupku utvrđenim sportskim pravilima. Ti kriterijumi moraju biti u skladu sa Zakonom o sportu i sportskim pravilima nadležnog međunarodnog sportskog saveza za odgovarajuću granu sporta i njima se ne može ograničavati pravo maloletnog sportiste na prelazak u drugu sportsku organizaciju koji nije povezan sa bavljenjem sportskim aktivnostima (obrazovanje, povezanost sa porodicom i dr.). Na sportska pravila kojima se uređuje transfer maloletnih sportista saglasnost daje Ministarstvo omladine i sporta, a nadležni nacionalni granski sportski savez je obaveza da obaveštava Ministarstvo u roku od 15 dana od svakog obavljenog transfera, odnosno registrovanog prelaska maloletnog sportiste.

\subsection{Zaštita od nasilja i diskriminacije}

Uprkos činjenici da sport promoviše etičke vrednosti, fer-igru i integritet, nasilje se javlja i u sportskom kontekst. Kao i u svim drugim oblastima koje uključuju blisku ličnu vezu i/ili autoritetski odnos prema deci, sportsko okruženje može ponekad izložiti maloletnike različitim oblicima nasilja i diskriminacije koji mogu dovesti do životnih posledica na njihovo emocionalno, fizičko i psihološko zdravlje, lični razvoj, društveni i porodični život, a zatim uticati na njihovo učešće u sportu i životu. Naročito je poslednja decenija ukazala na brojne slučajeve nasilja koje su deca i mladi spotisti doživeli u kontekstu sportskih aktivnosti. ${ }^{24}$ Poslednjih godina

22 Npr. škotski fudbalski klub Seltik potpisao je u decembru mesecu 2018. godine profesionalni ugovor sa 15-godišnjim Karamokoom Dembelom sa važenjem najmanje do 2021. Dembele je kao desetogodišnjak došao u Seltik. https://www.b92.net/sport/fudbal/vesti.php?yyyy=2018\&mm=12\&dd=25\&nav_ id $=1485924$

23 Lembo, op.cit.

24 Slučaj seksualnog zlostavljanja vrhunskih maloletnih gimnastičarki (među kojima i osvajači olimpijskih medalja Ali Raisman, Gabby Douglas, Simone Biles, McKayla Maroney, Madison Kocian, Kayla Ross), od strane reprezantivnog doktora Larria Nassara u okviru Američkog saveza gimnastičara, koji potresa svetsku gimnastiku poslednje dve godine, pokazao je da od zlostavljanja i zloupotreba nisu zaštićene ni najbolje maloletne sportiskinje i da u sportu postoji zavera ćutanja o tome. 
postalo je očigledno da sport nije uvijek siguran prostor za decu, i da se iste vrste nasilja i zloupotreba koja se ponekad nalazi u porodicama i zajednicama mogu se pojaviti i u sportu. Deca mogu biti zlostavljana tokom sportske aktivnosti, na putu ka takmičenju, nakon sportske aktivnosti, preko sovcijalnih medija, direktno ili indirektno. Nasilje može poticati od odrasle osobe ili mladog trenera ili drugog sportiste ili od strane njihovih vršnjaka ili bilo kog drugog iz pratnje, uključujući i roditelje. ${ }^{25}$ Paulo David, bivši sekretar Odbora za prava deteta, kancelarija Visokog komesara za ljudska prava Ujedinjenih nacija, grubo procenjuje da je od sve dece uključene u "takmičarski sport" $10 \%$ pretrpelo zloupotrebu ljudskih prava, a drugih $20 \%$ je izloženu riziku zloupotrebe. ${ }^{26}$

Posebno su osetljivi slučajevi seksualnog nasilja nad decom sportistima. ${ }^{27} \mathrm{Iz}$ više studija se može, načelno, zaključiti: elitni mladi sportisti su više seksualno napadnuti od svojih kolega u odnosu na sportiste iz nižih nivoa; tip sporta kojim se bavi mladi sportista nema uticaja; devojčice su češće seksualno zlostavljane u sportu od dečaka (mada su dečaci možda manje spremni da prijave ovu vrstu zlostavljanja); izvršioci seksualnog zlostavljanja su identifikovani kao prvenstveno ličnosti od autoriteta za mladog sportistu, posebno trenera, ali i timski lekari, instruktori ili "savetnici" (nisu isključeni slučajevi vršnjačkog seksulanog nasilja). ${ }^{28}$ U nekim slučajevima, nasilje je usmereno protiv osobe zbog svog / njenog pola (uključujući polni identitet ili izraz). Ovaj fenomen se shvata kao rodno zasnovano nasilje i može uključivati i seksualno uznemiravanje i zlostavljanje, silovanje, fizičko ili emocionalno-psihološko nasilje i LGBTI - nasilje. Ovi oblici rodno zasnovanog nasilja se međusobno ne isključuju već se preklapaju. ${ }^{29}$

Problem, međutim, leži i u samom definisanju pojma nasilja nad decom u sportu, jer se taj pojam može shvatiti u širem i užem smislu. U literaturi se pretežno taj pojam shvata veoma široko, u smislu čl. 19. Konvencije UN o pravima deteta: svaki oblik fizičkog ili mentalnog nasilja, povređivanja ili zlostavljanja, zapostavljanja ili nemarnog postupanja, maltretiranja ili eksploatacije, uključujući seksualno zlostavljanje, dok je dete pod brigom roditelja, zakonskih zastupnika ili bilo koje druge osobe koja se brine o detetu. U kontekstu sporta ta definicija pokriva sve oblike ponašanja koja krše pravila sporta, dovodeći do bolova, bilo fizičkih ili

25 Expert Group on Good Governance, Recommendations on the protection of young athletes and safeguarding children's rights in sport, Final document, July 2016, http://ec.europa.eu/transparency/ regexpert/index.cfm?do=groupDetail.groupDetailDoc\&id=25000\&no=1

26 Paulo David, Human Rights in Youth Sport: A critical review of children's rights in competitive sports, https://bura.brunel.ac.uk/bitstream/2438/524/3/Paulo+David+-+review+essay+(25.8.05).pdf

27 Istraživanje sprovedeno u Velikoj Britaniji u 2009. godini pokazalo je da je $29 \%$ uzorka sportista koji predstavljaju sve takmičarske nivoe bili seksualno uznemiravani (34\% žena i 17\% muškaraca), dok je $3 \%$ seksualno zlostavljano ( $5 \%$ muškaraca i 2\% žena). Slična studija koja je sprovedena u Danskoj među 250 mladih sportista pokazala je da je oko $25 \%$ bilo upoznato sa ili je doživelo situacije u kojima je trener seksualno uznemiravao učesnika u sportu mlađeg od 18 godina. Opšta je procena da su između 2\% i 8\% sportista (i maloletnika i mladih odraslih) žrtve seksualnog napada u kontekstu sporta (navedeno prema: Expert Group on Good Governance, op. cit.).

28 Expert Group on Good Governance, op. cit.

29 GENDER-BASED VIOLENCE IN SPORT, https://rm.coe.int/bis-factsheet-gender-equalitysport-violence-en/1680714c0c 
emocionalnih, i izlaganju neuobičajenih rizika od povreda, oštećenja ili smrti. ${ }^{30}$ Nasilje se tako usvaja kao najsveobuhvatniji pojam, jer obuhvata fizičke, seksualne i psihološke oblike maltretiranja, zlostavljanja, zloupotreba i napada. ${ }^{31}$

Nasilje nad decom u spotu može biti izraženo na više načina, uključujući: fizičko maltretiranje (namerne povrede, prisilni režimi, udaranje i drugi oblici fizičkog kažnjavanja kao podstrek za poboljšane performanse itd.); seksualno zlostavljanje, rečju ili akcijom (npr., potreban je seks kao preduslov za selekciju u tim ili dobijanje privilegije); zanemarivanje, uskraćivanje dovoljnog odmora i brige, nehuman tretman (sve što dete može trebati za njegov fizički rast i razvoj: medicinska nega, higijena, obrazovanje itd.); emocionalno i psihološko zlostavljanje; prekomerna obuka; obuka koja nije prilagođena individualnom fizičkom razvoju; nasilje, uznemiravanje i psihološka degradacija ili ponižavanje (na osnovu pola, rase, seksualne orijentacije, invaliditeta, oblika telja ili sposobnosti); doping, supstance koje povećavaju performanse ili neadekvatnu upotrebu lekova protiv bolova, dodataka za ishranu i / ili alkohol; intenzivna obuka na visokom nivou na štetu obrazovanja; maltretiranje, uključujući nasilje putem elektronskih komunikacija (cyber-bullying); obavezu mladih sportista da igraju kada su povređeni; korišćenje fizičke vežbe kao kazne; fizički štetne ili seksualno ponižavajuće rituale inicijacije (hazing); režimi ishrane i smanjenja telesne težine koji vode do poremećaja ishrane kao što je anoreksija ili drugim zdravstvenim problemima. ${ }^{32}$

Nasiljem nad decom u sportu često je povezano i sa određenim oblicima diskiminacije. Verbalno uznemiravanje, fizičko nasilje i isključivanje su među najčešće prijavljenim formama diskriminacije. Problem je, međutim, vezan i za tradicionalnu podelu sporta na muški i ženski sport. Sport je rodno iskustvo koje može ojačati rodne razlike i odnose moći između žena i muškaraca u društvu. ${ }^{33}$ Iako devojčice i dečaci mogu ponekad igraju zajedno u rodno mešovitim aktivnostima, u organizovanom sportu devojčice se, po pravilu, takmiče sa devojčicama i dečaci sa dečacima, tako da polne (rodne) razlike lako mogu postati faktor razdvajanja (razdora, otuđenja), pošto se dečaci često vide kao osobe koje poseduju superiorne atletske (telesne) veštine $u$ poređenju sa devojčicama. ${ }^{34}$ Rodno uznemiravanje

30 Expert Group on Good Governance, op. cit. (tačka 4. Definicije)

31 Prema definiciji utvrđenoj od strane Svetske zdravstvene organizacije u Svetskom izveštaju o nasilju i zdravlju iz 2002. godine: "Nasilje je namerno korištenje fizičke sile ili moći, preteće ili stvarno, protiv sebe, druge osobe, ili prema grupi ili zajednici, što je imalo za rezultat ili ima veliku verovatnoću da će doći do povrede, smrti, psihološkog oštećenja, lošeg (pogrešnog ili nesavršenog) razvoja ili deprivacije" http://apps.who.int/iris/bitstream/handle/10665/42495/9241545615 eng.pdf;jsessionid=452236B535658 2431FF0299C14F37D85? sequence=1

32 UNICEF Innocenti Research Centre op.cit., str. 4; David, op. cit..

33 Prema objavi Svetskog ekonomskog foruma za 2018. godinu, u svetu će za dostizanje jednakosti muškara i ćena na ekonomskom planu biti potrbnda dva veka a za zatvaranje jaza u rodnoj ravnopravnosti u celini više od 100 godina (http://rs.n1 info.com/Biznis/a445136/Izvestaj-Do-rodne-jednakosti-u-svetuproci-ce-108-godina.html).

34 Rodna diskriminacija se u sportu do sada suštinski tretirala kao pitanje polne diskriminacije (muški i ženski sport). Priznavanje postojanja „trećeg roda“, izraženo kroz brojne međunarodne i nacionalne propise, otvara nove dileme sa stanovišta sprečavanja diskriminacije u sportu. Nemački Parlament je u decembru 2018. godine odobrio izmenu propisa kojim se omogućava upis u matične knjige trećeg pola 
uključuje širok spektar verbalnih i neverbalno ponašanje koje prenose uvrede, neprijateljski ili ponižavajući stav o ženama. ${ }^{35}$ Diskriminacija na osnovu muškoženske, odnosno rodne podele tesno je povezana i sa homofobijom, toleranciojom "anti-gai" epiteta i selekcijom trenera / sportista na osnovu heteroseksualnog identiteta. Homofobija se preseca sa drugim oblicima uznemiravanja, kao što je diskriminacija lica sa invaliditetom, rasizam i seksizam. Oblici homofobičnog zlostavljanja u sportu uključuju: izloženost homofobičkim teškoćama i prisiljavanje na homoseksualne seksualne aktivnosti u inicijaciji i hazing ritualima; izlganje vršnjačkom nasilje ili stigmatizaciji; podvrgavanje direktnoj diskriminatornoj praksi u sportskim organizacijama; finansijsku diskriminaciju; diskriminacija od strane medija; prisiljavanje na neprimerena putovanja ili aranžmane spavanje sa drugim sportistima ili trenerima. ${ }^{36}$

Vlada Srbije je još 2005. usvojila Opšti protokol za zaštitu dece od zlostavljanja i zanemarivanja ${ }^{37}$, ali oblast sporta nije bila obuhvaćena ovim procesom, što se pokazalo kao ozbiljna prepreka za potpunu realizaciju prava deteta na zaštitu od nasilja. Zbog toga je Zakonom o sportu iz 2016. godine izričito propisana zabrana svake vrste zloupotreba, zlostavljanja, diskriminacije i nasilja prema deci (čl. 4. st. 6). Organizacije u oblasti sporta i lica koja obavljaju stručno-vaspitni rad sa decom u tim organizacijama, kao i svi članovi i zaposleni u organizacijama u oblasti sporta, obavezni su da promovišu ravnopravnost među decom i aktivno se suprotstavljati svim vrstama zloupotreba, zlostavljanja, diskriminacije i nasilja (čl. 4. st. 7. ZS). Sportista, odnosno drugo lice ima pravo na naknadu štete koju pretrpi aktima diskriminacije, zloupotreba, zlostavljanja i nasilja od strane organizacije ili lica u oblasti sporta (čl. 4. st. 9. ZS). Bliže uslove o načinima prepoznavanja oblika zlostavljanja, zloupotrebe, diskriminacije i nasilja nad decom u sportu sporazumno propisuju ministar nadležan za sport, ministar nadležan za unutrašnje poslove, ministar nadležan za pravosuđe i ministar nadležan za zdravlje (čl. 4. st. 8. ZS). Nadležna ministarstva još nisu donela propisani podzakonski akt (rok je bio 16. februar 2018. godine), ali je u toku rad na tom propisu. Prema Nacrtu pravilnika o bližim uslovima o načinu prepoznavanja oblika zlostavljanja, zloupotrebe, diskriminacije i nasilja nad decom u sportu iz septembra meseca 2018. godine:

- Zlostavljanje dece u sportu jeste svako aktivno ili pasivno ponašanje (uključujući i podsticanje i navođenje drugih na nedozvoljeno ponašanje) prema deci koje ima za cilj ili predstavlja povredu dostojanstva ili zdravlja dece i koje izaziva strah ili stvara za njega neprijateljsko, ponižavajuće ili uvredljivo okruženje koje dovodi do izolacije deteta i privremenog ili trajnog napuštanja trenažnog procesa, odnosno aktivnog bavljenja sportskim aktivnostima. Naročiti oblici zlostavljanja su: 1) uskraćivanje hrane, vode ili sna; 2) nedozvoljavanje adekvatnog odmora; davanje,

\footnotetext{
(roda): „različiti“ (http://www.politika.rs/sr/clanak/418116/Nemacki-parlament-odobrio-registracijutreceg-pola)

35 UNICEF Innocenti Research Centre, op.cit.

36 Ibid., str. 14.

37 https:// www. paragraf. rs/propisi / opsti_protokol_za_zastitu_dece_od_zlostavljanja_i zanemarivanja.html
} 
propisivanje, podsticanje, pomaganje i saučesništvo u korišćenju zabranjene doping supstance ili zabranjenog doping metoda; uvođenje režima ishrane koji su doveli ili mogu dovesti do poremećaja ishrane kao što je anoreksija ili drugih zdravstvenih problema.

- Zloupotreba dece u sportu jeste svako činjenje ili nečinjenje (uključujući i podsticanje i navođenje drugih na nedozvoljeno ponašanje) koje direktno utiče ili indirektno škodi deci ili im smanjuje mogućnost za bezbedan i zdrav razvoj i dovodi ih u nemoćan, neravnopravan i zavisan položaj. Naročiti oblici zloupotrebe su: 1) zahtevanje ili nuđenje seksualnih odnosa kao preduslova za odabir u tim ili davanje određene privilegije; 2) navođenje ili primoravanje dece u sportu na učešće u seksualnim aktivnostima, bilo da se radi o kontaktnim (seksualni odnos, seksualno dodirivanje i sl.) ili nekontaktnim aktivnostima (izlaganje pogledu, egzibicionizam i sl.); 3) seksualno uznemiravanje i to: neprimereno komentarisanje, dodirivanje (osim pomaganja i čuvanja u obučavanju i/ili izvođenju sportskog elementa tehnike i taktike u bilo kojoj sportskoj grani), upućivanje poruka, fotografisanje, telefonski pozivi i sl; i druge radnje uključivanja dece u sportu u seksualni kontakt koji ima za cilj da pruži uživanje ili zadovolji potrebe druge osobe.

- Nasilje nad decom u sportu jeste svaki oblik verbalnog ili neverbalnog ponašanja (uključujući i podsticanje i navođenje drugih na nedozvoljeno ponašanje), jednom učinjenog ili ponovljenog, koji ima za posledicu stvarno ili potencijalno ugrožavanje zdravlja, psihosocijalnog i motoričkog razvoja, obrazovanja i dostojanstva dece. Naročiti oblici nasilja su: 1) upotreba fizičke sile izvan sportskih pravila i drugi postupci koji naruše ili mogu narušiti detetov fizički integritet, zdravlje ili razvoj i to: udaranje, šutiranje, guranje, šamaranje, čupanje, davljenje, bacanje, gađanje, napad i pretnja oružjem, paljenje, posipanje vrućom ili ledenom vodom, telesno kažnjavanje ili druge forme fizičkog kažnjavanja; primoravanje na visoko rizične aktivnosti u ekstremnim uslovima koji su doveli ili mogu dovesti do povrede; korišćenje dodatnih fizičkih vežbi kao kazne; zahtevanje od deteta da učestvuje na takmičenju bez obzira na povredu ili bolest; 2) ponašanje koje dovodi do trenutnog ili trajnog ugrožavanja psihičkog i emocionalnog zdravlja ili razvoja i dostojanstva deteta i to: bilo koje ponašanje kojim se vrši omalovažavanje, ignorisanje, vređanje, ucenjivanje, nazivanje pogrdnim imenima, ogovaranje, podsmevanje, ismejavanje, iznuđivanje, manipulisanje, pretnja, zastrašivanje, ograničavanje kretanja; pritisak da se postižu bolji rezultati koji nisu u skladu sa opšteprihvaćenim trenažnim standardima, odnosno nisu u skladu sa psihofizičkim i razvojnim karakteristikama dece u određenom uzrastu; drugi slični oblici neprimerenog ponašanja; 3) uključivanje deteta u: neprimeren trenažni proces i takmičarske aktivnosti, gde se pod neprimerenim trenažnim procesom i takmičarskim aktivnostima podrazumeva takmičenje, odnosno trenažni proces koji dovodi do disfunkcije organizma usled fizičkih i psihičkih napora, odnosno socijalnih pritisaka, u okviru trenažnog procesa i takmičarske aktivnosti koji nisu adekvatno dozirani na trenutne funkcionalne mogućnosti, odnosno razvojne karakteristike dece, niti je planirana periodizacija koja je usklađena sa školskim obavezama dece; neusklađenost trenažnih aktivnosti sa školskim obavezama; neadekvatni uslovi za sprovođenje trenažnog procesa i 
takmičarske aktivnosti koji mogu dovesti do ugrožavanja zdravlja dece; pritisak da se postižu bolji rezultati koji nisu u skladu sa opšteprihvaćenim trenažnim standardima, odnosno nisu u skladu sa psihofizičkim i razvojnim karakteristikama dece u određenom uzrastu.

- Diskriminacija dece u sportu jeste svako neopravdano pravljenje razlike ili nejednako postupanje, odnosno propuštanje (isključivanje, ograničavanje ili davanje prvenstva), na otvoren ili prikriven način (uključujući i podsticanje i navođenje drugih na nedozvoljeno ponašanje), a koji se zasniva na rasi, boji kože, precima, državljanstvu, veroispovesti, nacionalnoj pripadnosti ili etničkom poreklu, jeziku, verskim ili političkim ubeđenjima, polu, rodnom identitetu, seksualnoj orijentaciji, imovnom stanju, rođenju, genetskim osobenostima, zdravstvenom stanju, invaliditetu, porodičnom statusu, izgledu, ili nekom drugom stvarnom ili pretpostavljenom ličnom svojstvu.

\section{PROTECTION OF CHILDREN IN SPORT}

Pursuant to the United Nations Convention on the Rights of the Child adopted in 1989, a child means every human being below the age of eighteen years unless under the law applicable to the child, majority is attained earlier. Every day vast number of children all over the world take part in sporting activities of recreational or competitive type in public spaces, schools, sport clubs or in other organisations. Those activities are supported and encouraged by their parents, numerous coaches, sport officials and other persons. Youth are engaging in sport at much younger age which is based on a fact that physical activity is a child's natural form of motions representing challenge and enjoyment brought by a game. For most of the children physical activities are positive life experiences enabling them to improve personal physical capabilities and their health condition and to develop social relations with others. However, there are also children whose engagement in sport is tied with adverse, even traumatic experiences as a result of discrimination, violence, abuse, exploitation, excessive coaching, impairment of health and undue influence to psychosocial and motorial abilities or education. All public authorities and participants in sport must decisively combat these adverse phenomena using relevant legal and social instruments. Sport in all forms must be individually accessible to every child without discrimination enabling equal opportunities for boys and girls with due respect to requirements of particular age. In this paper, the author points out the welfare that sport engagement brings to children considering typical forms of child abuse in sport and measures that need to be taken in order to protect children from various forms of discrimination, violence, abuse and exploitation in sport. The author also shows measures taken in that context at the international level, as well as accepted solutions from the Law on Sport of the Republic of Serbia adopted in 2016 concerning special protection of children in sport.

Key words: child safeguarding in sport, protection of children in sport, discrimination, violence, maltreatment, abuse, exploitation, sport, children. 